\title{
Giant cells lepromatous leprosy: Diffuse dermatitis with exuberant foreign body giant cells in treated lepromatous leprosy
}

\author{
Gerzaín Rodríguez ${ }^{1,2}$, Viviana Arias ${ }^{3}$ \\ ${ }^{1}$ Facultad de Medicina, Universidad de La Sabana, Chía, Colombia \\ ${ }^{2}$ Hospital Centro Dermatológico Federico Lleras Acosta, Bogotá, D.C., Colombia \\ ${ }^{3}$ Departamento de Patología, Facultad de Medicina, Universidad Nacional de Colombia, Bogotá, \\ D.C., Colombia
}

Patients with lepromatous leprosy that have received treatment for many years usually get follow up biopsies for persistent skin lesions or positive bacilloscopy even if the values are lower than in the initial bacilloscopy.

We report the case of a 48-year old woman with long-standing lepromatous leprosy of 15 years of evolution, with a bacterial index of 4 in the direct smear and the initial skin biopsy. The patient was treated with multidrug therapy for 32 months although the treatment recommended by the World Health Organization (WHO) is only for 12 months.

A skin biopsy was taken to determine if there was an active disease. We observed a diffuse dermal inflammation with numerous foreign body giant cells and vacuolated macrophages (Virchow's cells). These cells contained granular acid-fast material that was also positive with immunohistochemistry for BCG. There were fragmented bacilli and the BI was 2 . These cells were also strongly positive for CD68. The biopsy was interpreted as a residual form of lepromatous leprosy that did not require further multidrug therapy.

We have observed similar histological profiles in several cases. The lack of clinical data makes it a histological challenge. The accumulation of lipids in these giant cells is due to bacillary destruction and fusion of vacuolated macrophages. We discuss here the role of bacillary and host lipids in the pathogenesis of lepromatous leprosy. We concluded that there was no need to extend the 12-month multidrug therapy recommended by WHO. Clinical findings, bacilloscopy, annual skin biopsy, and anti-phenolic glycolipid-I IgM titers are recommended procedures for the follow-up of these patients.

Received: $07 / 05 / 18$

Accepted: $20 / 02 / 18$

Published: 21/02/19

Citation:

Rodríguez G, Arias V. Giant cells lepromatous leprosy: Diffuse dermatitis with exuberant foreign body giant cells in treated lepromatous leprosy. Biomédica. 2019;39(Supl.2):26-31.

https://doi.org/10.7705/biomedica.v39i4.4493

Corresponding author:

Gerzaín Rodríguez, Facultad de Medicina,

Universidad de La Sabana, Campus del Puente del

Común, Km 7, Autopista Norte de Bogotá, Chía,

Colombia

Telephone: (571) 861 5555, extension 23339; fax: (571) 8615555 , extension 2226

josert@unisabana.edu.co; gerzainrodriguez@gmail.com

Author contributions:

Gerzaín Rodríguez: Photographic images register, data gathering

Viviana Arias: Data analysis

Both authors contributed to the interpretation of data, the design of the manuscript, the search of references and the writing of the paper.

Funding:

No funding was needed for the preparation of this manuscript.

Conflicts of interest:

The authors declare no conflicts of interest.
Keywords: Leprosy; leprosy, multibacillary; leprosy, lepromatous; drug therapy, combination.

Células gigantes en lepra lepromatosa: dermatitis difusa con células gigantes exuberantes de tipo cuerpo extraño en lepra lepromatosa tratada

Los pacientes con lepra lepromatosa que han recibido tratamiento durante años, usualmente requieren seguimiento con biopsias de piel para detectar lesiones persistentes o si la baciloscopia es positiva, incluso si los valores son menores que los iniciales. Se presenta el caso de una mujer de 48 años de edad con lepra lepromatosa de 15 años de evolución, índice bacilar de 4 en el extendido directo y en la biopsia, que recibió tratamiento con múltiples medicamentos durante 32 meses, aunque lo recomendado por la Organización Mundial de la Salud (OMS) es una duración de 12 meses.

Se tomó una biopsia de piel para determinar si la enfermedad estaba activa. Se observó inflamación dérmica difusa con numerosas células gigantes de tipo cuerpo extraño y macrófagos vacuolados (células de Virchow). Estas células, CD68 positivas, contenían material granular ácido-alcohol resistente positivo con inmunohistoquímica para BCG. Se encontraron bacilos fragmentados y el índice bacilar fue de 2 . Se interpretó como una forma residual de lepra lepromatosa y se concluyó que la paciente no requería prolongar el tratamiento con múltiples medicamentos.

Este perfil histológico se ha observado en casos similares, pero sin datos clínicos estas biopsias representan un reto diagnóstico. La acumulación de lípidos en estas células gigantes se debe a la destrucción bacilar y a la fusión de macrófagos vacuolados. Se revisó el papel de los lípidos del bacilo y del huésped en la patogenia de la lepra lepromatosa. En estos casos, no es necesario extender los 12 meses de tratamiento con múltiples medicamentos recomendados por la OMS. En el seguimiento de los pacientes, se recomienda contar con los hallazgos clínicos, la baciloscopia, la biopsia anual de piel y los títulos IgM antiglucolípido fenólico.

Palabras clave: lepra; lepra multibacilar; lepra lepromatosa; quimioterapia combinada. 


\section{Clinical case}

We report the case of a 48-year old woman who had presented for 15 years with red plaques that started in the legs and spread to arms, thorax, and abdomen. She had auricular nodules, cheek papules, perforation of the nasal septum, bilateral ulnar thickening, thenar and hypothenar atrophy, and ulcers in the legs and ankles. Lesions were anesthetic. Bacilloscopy revealed a bacillary index of 4 and the skin biopsy showed diffuse dermal infiltrate of foamy macrophages, (Virchow's cells) with acid-fast bacilli (AFB) and globii. Nerves had lamellar perineural thickening with intra-neural inflammation and abundant phagocyted bacilli in Schwann's cells.

As the diagnosis was lepromatous leprosy, multidrug therapy was prescribed with rifampin, clofazimine, and dapsone $(1,2)$. On her last medical appointment, the patient reported that she had taken multidrug therapy monthly for 32 months. Some brown plaques and papules persisted in several parts of the body, but no new lesions had appeared. The bacillary index was 2 in the skin smear.

A biopsy was taken from a forearm papule to determine the existence of active lepromatous leprosy. It was a $4 \times 4 \mathrm{~mm}$ cylindric biopsy without hypodermis, which was processed with hematoxylin-eosin (HE) and FiteFaraco staining (FF staining), as well as immunohistochemistry (IHC) for S100, CD68, and BCG.

The biopsy showed diffuse dermal infiltration mostly consistent of prominent multinucleated giant cells with large cytoplasmic vacuoles, some of them of more than $100 \mu \mathrm{m}$ diameter, containing amorphous or granular, slightly basophilic material with occasional granular forms that were diffusely positive with the FF staining and BCG IHC (figures 1 and 2).

There were large groups of giant cells separated by thick collagen septa. We observed numerous vacuolated macrophages (Virchow's cells) and few lymphocytes and plasma cells. No nerves were identified by $\mathrm{S} 100$ IHC. Immunohistochemistry for CD68 was positive in the scarce cytoplasm surrounding the vacuoles inside the giant cells and in the vacuolated macrophages of the infiltrate (figure 3).

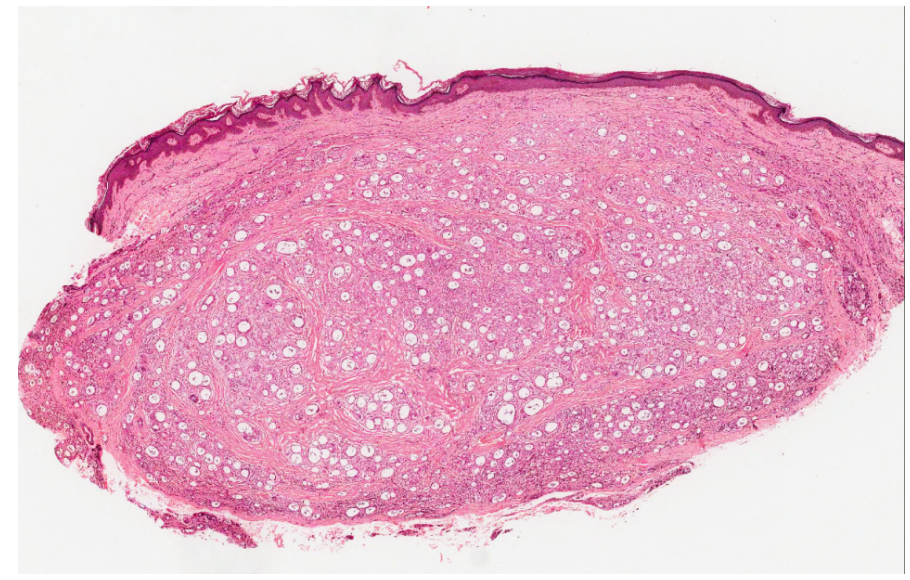

Figure 1A. Skin biopsy showing irregular epidermis and dermis with superficial fibrosis and diffuse granulomatous infiltrate rich in giant cells with enormous vacuoles and foamy macrophages. Dense collagen bundles surround granulomas. Hematoxylin eosin, $1 \mathrm{X}$

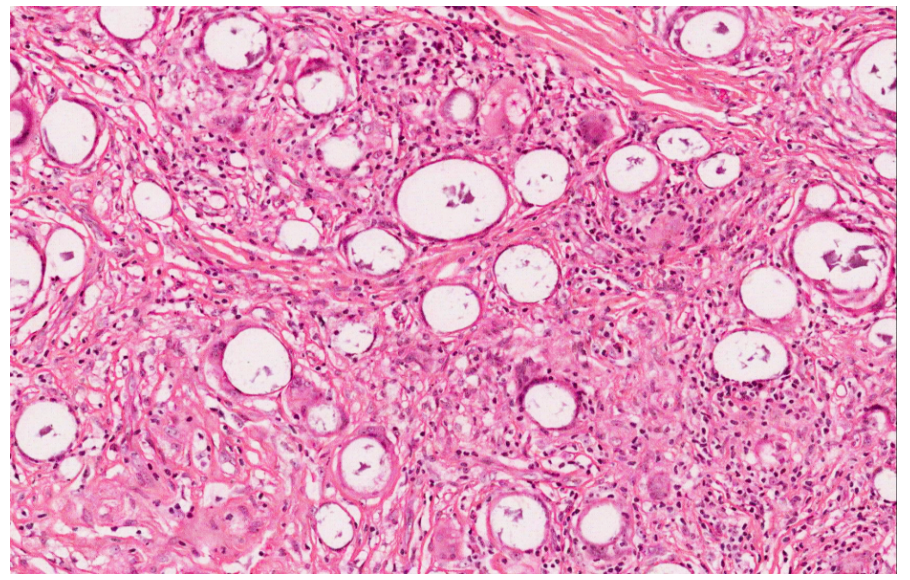

Figure 1B. Giant cells with large vacuoles containing basophile amorphous scarce material. Foamy macrophages (Virchow's cells), few lymphocytes, and plasma cells are present. Hematoxylin eosin, 20X. 


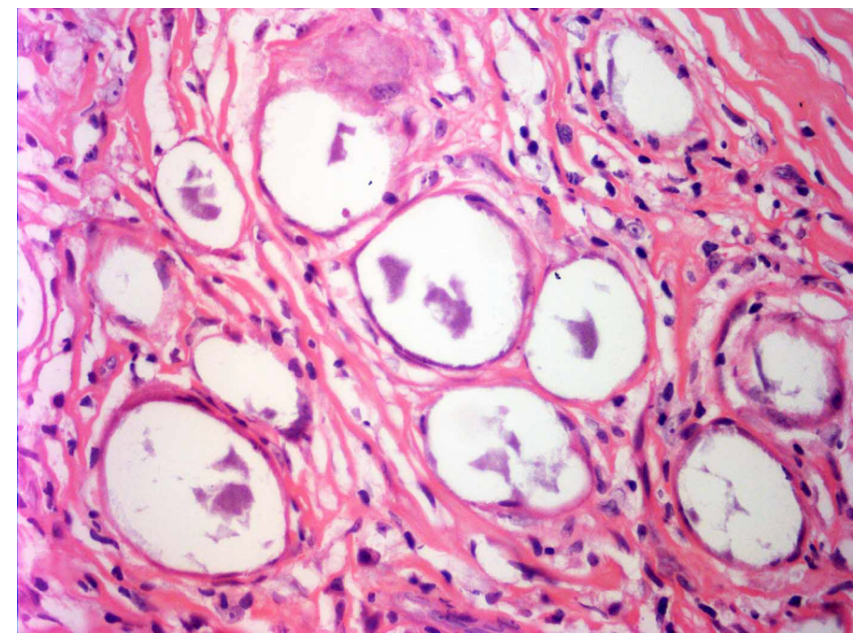

Figure 1C. Giant cells with large central vacuoles and scarce and thin peripheral cytoplasm containing amorphous material. Hematoxylin eosin, 40X.

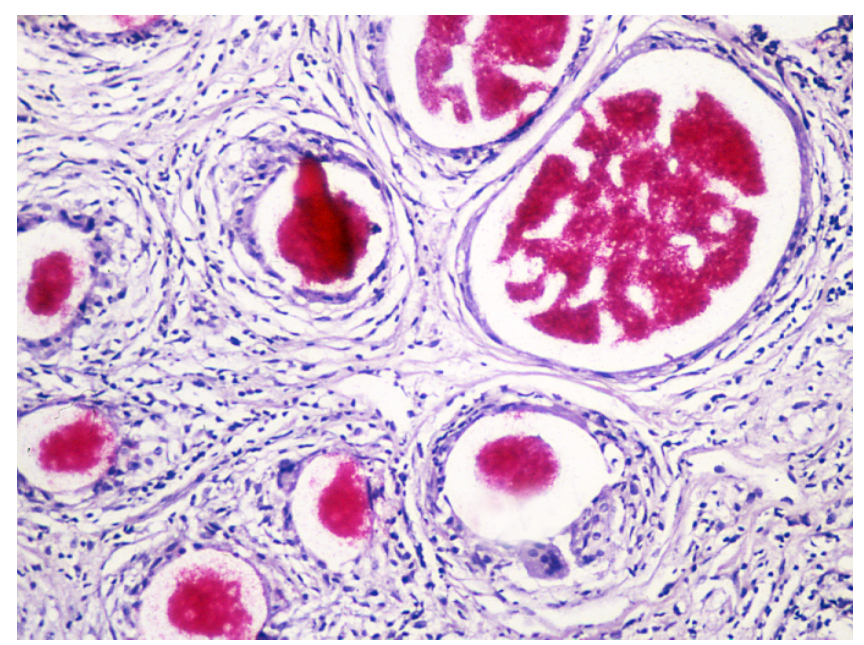

Figure 2A. Acid-fast mass inside the vacuoles of giant cells. FiteFaraco, 20X.

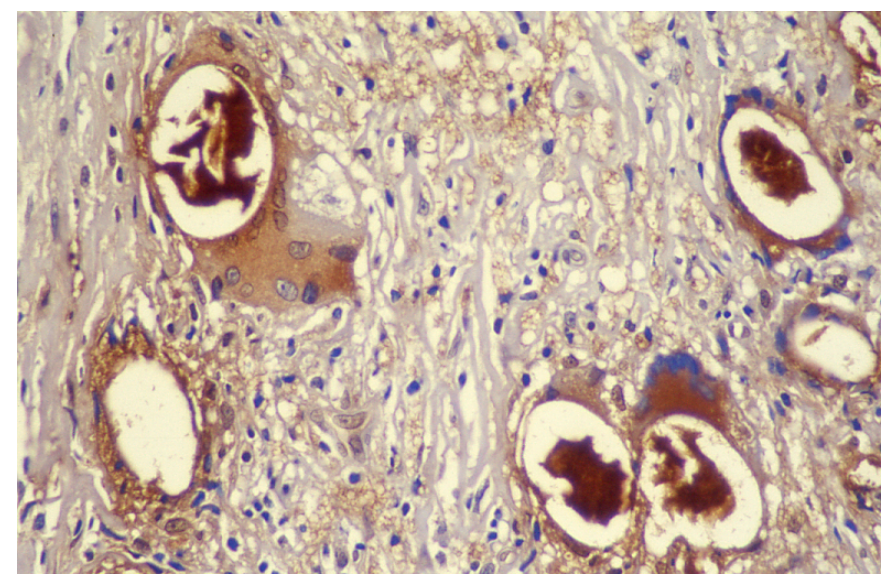

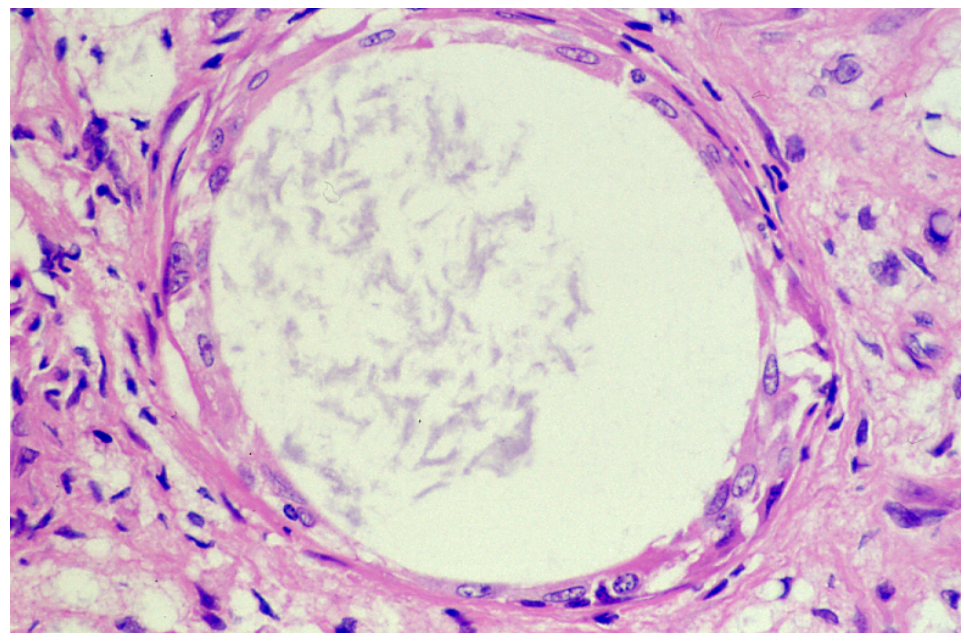

Figure 1D. Giant multinucleate cell with filamentous material in the vacuole and thin cytoplasm surrounded by foamy macrophages. Hematoxylin eosin, 50X.

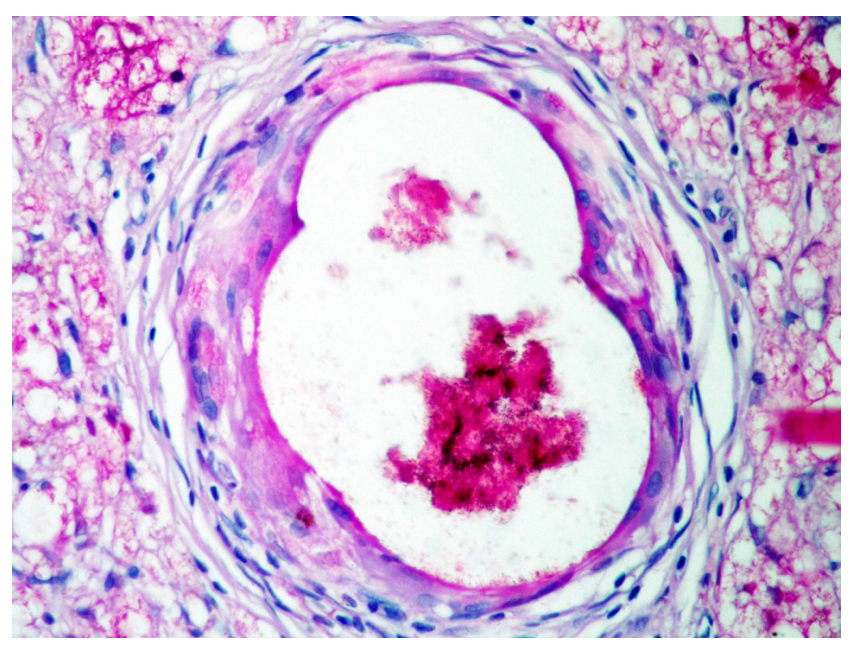

Figure 2B. Fite-Faraco staining positivity in the contents of a vacuole of a giant cell and in the cytoplasm of neighboring macrophages. Fite-Faraco, 40X.
Figure 2C. Strong positivity in cytoplasm of giant cells and slight in the cytoplasm of surrounding foamy macrophages. BCG immunohistochemistry, 40X. 

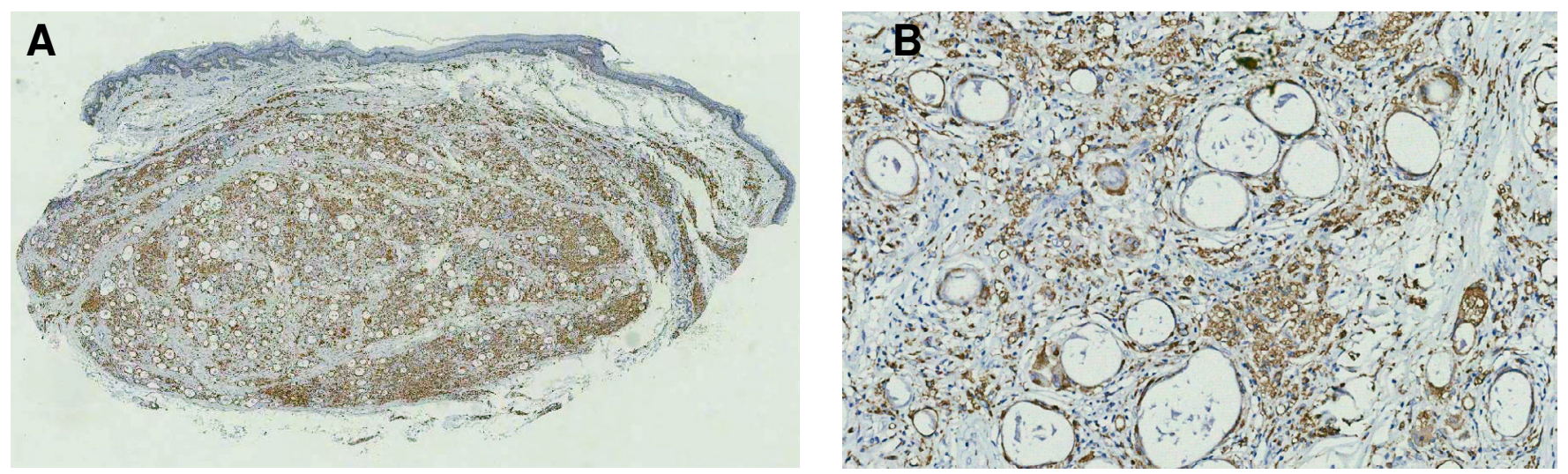

Figure 3. A. Diffuse positivity of cells for CD68. Immunohistochemistry, 2X. B. Only the thin cytoplasm of giant cells stains with CD68. Immunohistochemistry, 20X

\section{Discussion}

We report the case of a woman with long-standing lepromatous leprosy treated with multidrug therapy during 32 months because she had persistent papular and infiltrated lesions in the skin, although the World Health Organization $(\mathrm{WHO})$ recommends a twelve-month therapy $(1,2)$.

We have observed similar histological findings in cases where active disease is suspected. The cytoplasmic vacuoles of more than $100 \mu \mathrm{m}$ in foreign body giant cells contain granular or filamentous material that is positive with FF staining and BCG immunohistochemistry and is indicative of residual fragments of Hansen bacilli destroyed by the treatment. BCG immunohistochemistry stains most of the mycobacteria and their dissociated components (3). We did not find complete bacilli.

Fibrosis inside the granulomas is a sign of lesion regression. All the inflammatory process explains the clinical lesions, but it also indicates there is not active lepromatous disease and that multidrug therapy does not need to be continued. The physician continues the therapy based on bacilloscopy, which is positive due to the presence of acid-alcohol resistant granules in the smear with a bacillary index of 1 to 2 that is lower than the value registered at admission. Physicians usually try to eliminate the clinical lesions with multidrug therapy, but these bacterial remains are not eliminated with this therapy and macrophages end up eliminating them over the years (4).

Lipid accumulation in the macrophages in lepromatous leprosy is induced by the bacillus, which promotes the formation of lipid vacuoles or adiposomes that constitute an intracellular ecologic niche protecting the bacillus from immunological response, making it impermeable to several compounds and medications, supplying nutrients, and allowing it to survive inside the macrophage for years (5-8).

Lipid components of the bacillus cell wall adhere to TLR2 and TLR6 receptors of the macrophage to be internalized in its cytoplasm (5-9). This process gives origin to molecular messages that propitiate local accumulation of cholesterol and its esters, which facilitate the entrance of new bacilli to the macrophage. Lipid cytoplasmic vacuoles, rich in diverse lipids, are also formed; they join the phagosome and contribute to an ideal environment for bacillary survival (5-9). These lipid vacuoles or adiposomes are cellular organelles induced by the bacillus, and they include eicosanoids such as 
prostaglandin E2, which induces the macrophage to carry out a Th2 immune response with production of interleukin 10 (IL-10) and abolition or decrease of interleukin 12 (IL-12), gamma interferon (IF $\vee$ ) and nitric oxide leading to the inhibition of the Th1 immune response in order to avoid the macrophage attacking the bacillus (5). The macrophage genes activated by the bacillus also induce the production of phospholipases, which help to produce oxidized phospholipids and inhibit the immune response of the host (8).

Mycobacterium leprae induces the expression of the protein related with the adipose/adipophilin differentiation (ADRP) and with the peripilin, which promotes the accumulation of lipids in the macrophage and suppresses the expression of hormone-sensitive lipases so that lipids are not digested $(5,6)$. Oxidized phospholipids also form in the phagosomic vacuole surrounding the cellular wall of the bacillus, which is one of its more protective components (9). An essential component of the cellular wall of M. leprae is phenolic glycolipid-I (PGL-I), which allows the entrance of the bacillus to cells, including the Schwann cells, and induces immune Th2 response, prevents phagosome-lysosome fusion and is antigenic. The antibody IgM titles against PGL-I diminish significantly when the antileprosy treatment is successful and explains its utility as a diagnostic and treatment control test in leprosy (5-7).

As the result of the lepromatous leprosy treatment, the size of the vacuolated macrophages increases as prominent cytoplasmic vacuoles are formed full of lipids, which suggests that they originate in bacillary disintegration due to the treatment (10). Sixty percent of the dry weight of the Hansen bacillus corresponds to lipids (5). Nevertheless, in cultured macrophages infected with $M$. leprae, it has been shown that clofazimine activates the formation of lipases and diminishes the accumulation of lipids inside the macrophage and that it also induces the production of interferons, all of which contributes to bacillary elimination (9). Macrophages may take an ochre look resulting from clofazimine accumulation in the HE stain.

The bacillary fragments appear in these vacuoles as granular acid-fast forms. There is a confluence of macrophages forming these voluminous cells, which may also contain cholesterol crystals. The rupture of macrophages and their phagocytosis contribute to this increase in cell size and to the formation of giant cells with the aspect of those appearing by the phagocytosis of free cholesterol (11).

As of 2007, WHO recommends treating multibacillary leprosy with three medications: rifampin, clofazimine, and dapsone for one year. This treatment is considered sufficient and relapses are few $(1,2,12,13)$. Patients should have a bacilloscopy and skin biopsy at the end of the treatment and in annual follow-ups to compare the histologic findings and bacillary index values (4). Together with clinical findings, these methods are very helpful to determine if there is persistence or recurrence of the disease.

The viability studies of $M$. leprae in skin samples of patients with treated multibacillary leprosy carried out with mouse footpad inoculation and fluorescent microscopy have shown the possibility of recurrence of the disease in $3.3 \%$ of patients with high bacillary index and viable bacilli in the skin after 12 doses of treatment $(12,13)$. The appearance of erythema nodosum leprosum is also possible, but the characteristics of the clinical lesions and the skin biopsy allow to clarify the diagnosis. 


\section{Conclusion}

Lepromatous leprosy patients may present with residual clinical lesions when they have received the appropriate treatment or prolonged treatment for more than one year. The histological study of these lesions shows a diffuse pattern of vacuolated macrophages rich in giant cells of the foreign body type resulting from host lipolysis and mycobacteria lipids.

Without the medical history of the patient, the images from the histological study are a diagnostic challenge for the pathologist. The lesions disappear gradually and do not require anti-leprous treatment. FF staining may show acid-fast conglomerates or granular forms in the vacuoles, but not complete bacilli. BCG IHC does not identify them either.

The clinical and histological signs of inactivity and healing of leprosy should be known in order to avoid prolonged unnecessary medication. Clinical findings, comparative studies of smear tests, and biopsies, as well as IgM anti-PGL-I titles, are useful procedures to determine the cure or the persistence of the disease.

\section{Ethical considerations}

Informed consent was not required as the data were analyzed anonymously.

\section{References}

1. Rodríguez G, Pinto R. La lepra. Imágenes y conceptos. Medellín: Universidad de Antioquia y Universidad de La Sabana; 2007. p. 128-36.

2. McDougall AC. Recent developments in the chemotherapy of leprosy. Lepr Rev. 1997;68:194-9.

3. Molina-Ruiz AM, Cerroni L, Kutzner H, Requena L. Immunohistochemistry in the diagnosis of cutaneous bacterial infections. Am J Dermatopathol. 2015;37:179-216. https://doi.org/10.1097/DAD.0000000000000227

4. Scollard DM. Pathogenesis and pathology of leprosy. Accessed: September 29, 2017. Available from: https://www.internationaltextbookofleprosy.org/sites/default/files/ITL_2_4\%20FINAL_0.pdf

5. Kaur G, Kaur J. Multifaceted role of lipids in Mycobacterium leprae. Future Microbiol. 2017;12:315-35. https://doi.org/10.2217/fmb-2016-0173

6. Mattos KA, Sarno EN, Pessolani MCV, Bozza PT. Deciphering the contribution of lipid droplets in leprosy: Multifunctional organelles with roles in Mycobacterium leprae pathogenesis. Mem Inst Oswaldo Cruz. 2012;107(Suppl.1):156-66.

https://doi.org/10.1590/S0074-02762012000900023

7. Guenin-Macé L, Simeone R, Demangel C. Lipids of pathogenic mycobacteria: Contributions to virulence and host immune suppression. Transbound Emerg Dis. 2009;56:255-68. https://doi.org/10.1111/j.1865-1682.2009.01072.x

8. Cruz D, Watson AD, Miller CS, Montoya D, Ochoa M-T, Sieling PA, et al. Host-derived oxidized phospholipids and HDL regulate innate immunity in human leprosy. J Clin Invest. 2008;118:2917-28. https://doi.org/10.1172/JCl34189

9. Degang Y, Akama T, Hara T, Tanigawa K, Ishido Y, Gidoh M, et al. Clofazimine modulates the expression of lipid metabolism proteins in Mycobacterium leprae-infected macrophages. PLoS Negl Trop Dis. 2012;6:e1936. https://doi.org/10.1371/journal.pntd.0001936

10. Ridley DS. Skin biopsy in leprosy. Second edition. Basle: Documenta Geigy; 1995. p. 112-21.

11. Majno G, Joris I. Symptoms of cellular disease: Intracellular accumulations. In: Majno G, Joris I, editors. Cells, tissues and disease. Second edition. New York: Oxford Academic Press; 2004. p. 75-112.

12. Kumar A, Girdhar A, Girdhar BK. Twelve months fixed duration WHO multidrug therapy for multibacillary leprosy: Incidence of relapses in Agra field-based cohort study. Indian J Med Res. 2013;138:536-40.

13. Ebenezer GJ, Daniel S, Norman G, Daniel E, Job CK. Are viable Mycobacterium leprae present in lepromatous patients after completion of 12 months' and 24 months' multi-drug therapy? Indian J Lepr. 2004;76:199-206. 